\title{
Efficacy of fresh crushed leaves and essential oil of Eucalyptus camaldulensis Dehnh on larvae of Dermestes maculatus De Geer insect damage to smoked dried Sardinella aurita "Kétiakh" stored in Senegal
}

\author{
Oumar GUEYE ${ }^{1 *}$, Néné Gallé FALL ${ }^{1}$, El Hadji Barka NDIAYE², Khamath SENE², \\ Lassana KEITTA ${ }^{3}$ and Momar Talla GUEYE ${ }^{4}$
}

\begin{abstract}
${ }^{1}$ Atelier Poisson et Produits Halieutiques, Institut de Technologie Alimentaire, Hann-Dakar BP 2765, Sénégal.
${ }^{2}$ Département de Chimie, Faculté des Sciences et Techniques, Université Cheikh Anta Diop, BP 5005 Dakar, Sénégal.

${ }^{3}$ UFR des Sciences Agronomiques, d'Aquaculture et de Technologie Alimentaire (S2ATA), Université Gaston Berger BP 234 Saint Louis, Sénégal.

${ }^{4}$ Laboratoire des Analyses Phytosanitaires, Institut de Technologie Alimentaire, Hann-Dakar BP 2765, Sénégal.

*Auteur correspondant, E-mail : gueyeniaye87@gmail.com ; omgueye@ita.sn ; Tél.: (+221) 774270006.
\end{abstract}

\author{
Received: 15-04-2021 $\quad$ Accepted: 06-08-2021 $\quad$ Published: 31-08-2021
}

\begin{abstract}
Synthetic pesticides used to protect stored smoked and dried fish often cause enormous damageto human health and the environment. To limit the harms due to the use of these chemicals, it is necessary to find alternative methods. For this purpose, natural substances may constitute a beneficial way. The objective of this work is to study the effect of crushed fresh leaves and essential oil of Eucalyptus camaldulensis on the mortality of the larvae of an insect pest of smoked and dried fish, Sardinella aurita "Kétiakh", Dermestes maculatus (De Geer, 1774). Essential Oil was obtained by steam distillation from Eucalyptus leaves $(0.8 \% \mathrm{w} / \mathrm{w})$ and analyses carried out by GC/FID and GC/MS. For the biological test, fresh crushed leaves and essential oil were tested at different doses at varying treatment times again larvae Dermestes maculates. The results showed that D. maculatus was sensitive for both fresh crushed leaves and the essential oil, the efficacy of which depended on the dose and duration of treatment. The doses of $2 \mathrm{~g}$ and $2.5 \mathrm{~g}$ of freshly ground leaves showed a high efficiency of 27 to $40 \%$, of mortality respectively. However, for the essential oil, with the increase in the duration of exposure, the highest mortality (33.3\%) was recorded after 72 hours of treatment with the $40 \mu 1$ dose and at 120 hours with the $60 \mu 1$ dose. This study showed that fresh crushed leaves and essential oil of Eucalyptus camaldulensis can be considered as an alternative to the use of chemical insecticides in the conservation of smoked and dried Sardinella aurita "Kétiakh"stored in Senegal.
\end{abstract}

(C) 2021 International Formulae Group. All rights reserved.

Keywords: Eucalyptus camaldulensis, fresh leaves, essential oil, smoked and dried fish "Kétiakh", Sardinella aurita, Dermestes maculatus 


\section{INTRODUCTION}

The "Kétiakh" (smoked and dried Sardinella aurita), is one of the processed fish products that provides an important part of the food for more than half of the Senegalese population. It is also exported throughout West and Central Africa where it is used as food or condiments added to several traditional meals (Fall et al., 2014). Unfortunately, this product is very often characterized by low and unstable yields. This is due, in particular, to their susceptibility to insect infestations (Koch et al., 2016). Indeed, during storage, the "Kétiakh" is rapidly attacked by predatory insects such as the Dermestidae beetles, of which Dermestes maculatus appears to be the most frequently encountered and in high density on the latter (Gueye-NDiaye, 1991). Storage, which is essential to meet the population's needs for braised, salted and dried "Kétiakh" fish and to ensure food security, is a problem to which special attention must be paid (Janin, 2010). Thus, faced with this situation, the processors use chemical products in an abusive way (dosage not respected) making the finished product unfit for consumption (food poisoning, health problems ...). The latter are effective but very dangerous, especially with producers who do not have the necessary knowledge and technicity (Gueye, 2012). The cost, quality, and high toxicity of these products have made it necessary to find alternatives to reduce postprocessing losses and increase the availability and safety of traditional fish products for human consumption.

Unfortunately, from their intensive use, many undesirable effects arise such as: environmental pollution, disposal of auxiliaries, food poisoning, bioaccumulation phenomena, etc. (Guèye et al., 2011). To this end, the search for effective but non-chemical alternatives can alleviate, among other things, the problems related to the residues present in the "Kétiakh". According to Ndiaye et al. (2018), insects control with repellent products (essential oils or plant-emitted Volatile Organic Compounds, VOCs) seems to be, at least locally, a good alternative to synthetic formulations whose bio-active constituents lead often to insect resistance and toxicity for man and other living organisms. Vegetable substances are among environmentally friendly strategies to reduce health and ecological problems may be a beneficial way forward.

It is in this context of research into alternative control methods to reduce postprocessing losses of braised-dried fish, "Kétiakh" due to D. maculatus as a substitute for synthetic pesticides that this work is being carried out. Essential oils, like those of Eucalyptus, by their larvicidal properties, can be used in the conservation of "Kétiakh" as substitutes for pesticides because they are accessible to producers. Indeed, Eucalyptus is planted mainly for its leaves, which have larvicidal effects and medicinal properties but also for their higher content in essential oils. These are exploited for their use in pharmacy and perfumery applications (Elaissi et al., 2012; Siddiqui et al., 2000). Cheng et al. (2009) showed the effectiveness of eucalyptus essential oils against mosquito larvae. Several studies on the chemical composition of essential oils of eucalyptus reported 1.8cineole as main compound: Francisco et al. (2001) on E. camaldulensis of Maputo with $43.4 \%$, E. camaldulensis of Morocco 50.69\% and in Iran $69.46 \%$ and $54.37 \%$ (Farah et al., 2002; Medhi et al., 2010; Panahi et al., 2011). The general objective of this study is to test in the laboratory, the effectiveness of essential oil (HE) and fresh crushed leaves of Eucalyptus camaldulensis in the protection of stored smoked and dried Sardinella aurita against Dermestes maculatus.

\section{MATERIALS AND METHODS}

Plant material and extraction of essential oil The fresh leaves of Eucalyptus camaldulensis were harvested in Dakar (Hann Zoological Park). Identification of species was confirmed in the Vegetable Biology Department of Cheikh Anta Diop University (Dakar). Botanicals specimens were deposited in the herbarium of "Institut Fondamental d'Afrique Noire" (IFAN) of Cheikh Anta Diop University (Dakar).

The freshly harvested plant material was washed with distilled water. One part was dried for 3 days in the shade at room 
temperature and the other part is freshly crushed.

To extract the essential oil, the Eucalyptus camaldulensis dried for 3 days are subjected to steam training for 4 hours (with 1.5 liter of water) using a Clevenger-type device.

\section{Analysis of essential oils}

Oils and extracts from aqueous distillates were analysed by gas chromatography fitted with a flame ionization detector (GC-FID) and gas chromatography coupled with a mass spectrometer (GC-MS).

GC-FID: The gas chromatograph fitted with a flame ionization detector (ThermoTrace, Interscience, Belgium) was equipped with an optima-5-MS Accent capillary column from Agilent (Belgium) ( $30 \mathrm{~m}$ x $0.25 \mathrm{~mm}$ x 050 $\mu \mathrm{m}$ film thickness for a complete resolution of 1,8-cineole and limonene which co-eluted with thinner stationary phases). The oven temperature ranges from 40 to $250{ }^{\circ} \mathrm{C}$ according to the following programme: $40{ }^{\circ} \mathrm{C}$ for $3 \mathrm{~min}$ and then a programmation at 5 ${ }^{\circ} \mathrm{C} / \mathrm{min}$ until $250{ }^{\circ} \mathrm{C}$ with a final hold of $5 \mathrm{~min}$ at this temperature. Helium (He) was used as carrier gas at a flow rate of $1.1 \mathrm{ml} / \mathrm{min}$. The injector used in splitless mode was set at 280 ${ }^{\circ} \mathrm{C}$. The detector (FID) temperature was 280 ${ }^{\circ} \mathrm{C}$. The FID runs with compressed air (at a flow of $350 \mathrm{~mL} / \mathrm{min}$ ) and hydrogen (35 $\mathrm{mL} / \mathrm{min}$ ). A make-up gas (N2) was used with a flow rate of $30 \mathrm{~mL} / \mathrm{min}$. GC-MS: The gas chromatograph (Agilent 6890-USA) equipped with MS (Agilent 5973 NETWORK mass selective detector) in the electron impact mode $(70 \mathrm{eV})$ source and quadrupole temperatures were of 280 and $150{ }^{\circ} \mathrm{C}$, respectively. The scanned mass range was fixed at 35-350 amu. The column was the same than GC-FID. The oven temperature was programmed as follows: isotherm of $5 \mathrm{~min}$ at $40{ }^{\circ} \mathrm{C}$ then a progression of $8{ }^{\circ} \mathrm{C} / \mathrm{min}$ up to $280^{\circ} \mathrm{C}$ with a final hold of 5 $\min$ at $280{ }^{\circ} \mathrm{C}$. The injector, used in splitless mode, was at $240{ }^{\circ} \mathrm{C} .1 \mu \mathrm{l}$ of each sample was injected. The carrier gas was Helium (He) with a constant flow rate of $1.1 \mathrm{~mL} / \mathrm{min}$. The identification of the compounds was made using data of computer library (Wiley 275L) connected to the GC-MS and retention indices of components were calculated using retention times of n-alkanes (C7-C30) and compared with those of the literature (Joulain and Konig, 1998 ; Adams, 2001).

\section{Insects used}

D. maculatus adults used were collected at Mbour specifically at the Mballing processing site from infested dried braised fish. Then, they were maintained in mass breeding under the laboratory environmental conditions (temperature $\left(22 \pm 4{ }^{\circ} \mathrm{C}\right)$ and relative humidity $(80 \pm 5 \%))$ in one liter pots. After emergence, larvae from mass rearing were used for toxicity testing.

\section{Dried and smoked fish Sardinella aurita "Kétiakh"}

Dried and smoked Sardinella aurita samples used for the mass rearing of adults of D. maculatus and the others bioassay tests were bought on a Dakar market (Castor). They are not subjected to any treatment with insecticides or other chemical compounds that may influence testing.

\section{Toxicity testing}

\section{Fumigation test with Eucalyptus camaldulensis essential oil}

Five larvae of D. maculatus were placed with $20 \mathrm{~g}$ of dried and smoked Sardinella aurita in half-liter jars. Doses of $60 \mu \mathrm{L}, 70 \mu \mathrm{L}$, $80 \mu \mathrm{L}$ and $90 \mu \mathrm{L}$ of Eucalyptus camaldulensis essential oil were tested (Table 1). The essential oil was deposited using a micropipette on a washer of filter paper stuck to the wall of the lid of each jar for good diffusion and also to avoid direct contact with the product. Each treatment was repeated 3 times.

\section{Contact test with fresh crushed leaves of Eucalyptus camaldulensis}

The experimental design was subdivided into 3 treatments (Table 1) repeated three times. The tests were carried out in glass jars of $1 / 2$ liter with perforated lids to allow good ventilation. The method is to introduce in each jar, $20 \mathrm{~g}$ of dried and smoked Sardinella aurita with the doses $2 \mathrm{~g}, 2.5 \mathrm{~g}$ and $3 \mathrm{~g}$ of crushed fresh leaves. After the introduction of the 
different doses, the jars were heavily shaken (1 to $2 \mathrm{~min}$ ) and then stabilized for 5 to $10 \mathrm{~min}$ in order to homogenize the deposit of particles and then five larvae of $D$. maculatus were introduced into each jar. An untreated control and a control treated with Actellic (1.6\% pirimiphos-methyl and $0.3 \%$ permethrin by mass) were used as references for the toxicity tests.

\section{Mortality evaluation}

Daily insect mortality monitoring was carried out over 24, 72 and 120 hours. The evaluation consisted of the census of dead insects and was removed from the jars while the survivors were returned to the jars. Abbott,
(1925) formula below was used to correct for natural mortality.

Mcorr $=\left(\frac{M t-M c}{100-M c}\right) \times 100$

Mcorr $=$ adjusted mortality $(\%)$

$\mathrm{Mt}=$ Mortality in the treated group

$\mathrm{Mc}=$ Mortality in the negative control group

\section{Statistical analysis}

Statistical analyses of the variables measured were performed with XL-STAT 6.1.9 software. The data obtained were subjected to the ANOVA variance analysis and the averages compared by the Fisher test at 5\%.

Table 1 : Experimental design.

\begin{tabular}{lcccccccc}
\hline \multirow{2}{*}{ Formulation } & \multicolumn{2}{c}{ Control } & $\begin{array}{c}\text { Eucalyptus camaldulensis } \\
\text { essential oil }\end{array}$ & \multicolumn{3}{c}{$\begin{array}{c}\text { Fresh crushed leaves of } \\
\text { Eucalyptus camaldulensis }\end{array}$} \\
\cline { 2 - 9 } & Négative & $\begin{array}{c}\text { Positive } \\
\text { (actellic) }\end{array}$ & & $\begin{array}{c}\text { Dose } \\
(\boldsymbol{\mu} \mathbf{L})\end{array}$ & \multicolumn{3}{c}{$\begin{array}{c}\text { Fresh leaves } \\
(\mathbf{g})\end{array}$} \\
\hline Treatment & $\mathrm{T} 0$ & $\mathrm{~T} 1$ & $\mathrm{~T} 2$ & $\mathrm{~T} 3$ & $\mathrm{~T} 4$ & $\mathrm{~T} 5$ & $\mathrm{~T} 6$ & $\mathrm{~T} 7$ \\
\hline Dose & 0 & 0,125 & 20 & 40 & 60 & 2 & 2,5 & 3 \\
\hline
\end{tabular}

\section{RESULTS}

\section{Gas chromatographic analysis}

The results of essential oils analysis are presented in Table 2. A total of 57 compounds were identified in the volatile profile of the essential oils from Dakar, representing more than $94.5 \%$ of the total oil components which were detected (Table 1). The main constituent was $\beta$-pinene at $26.8 \%, \alpha$-eudesmol $(19.2 \%)$, epiglobulol (7.9) $\gamma$-eudesmol $(6.1 \%)$ and $\alpha$ pinene $(4.5 \%)$. These percentages of $\beta$-pinene and $\alpha$-pinene explain the high content of hydrocarbon monoterpenes with $41.0 \%$. This chemical group was marked by the presence of $\alpha$-thujene $(0.2)$, myrcene $(0.5 \%)$, limonène (4.4\%) and $\beta$-phellandrene (2.0\%). Oxygenated sesquiterpenes were present with (38.8\%). Hydrocarbon sesquiterpenes such as $\gamma$-gurjunene $(1.1 \%)$ bicyclogermacrène $(1.1 \%)$ aromadendrène $\quad(0.8 \%), \quad \beta$-caryophyllene $(0.7 \%) \quad \gamma$-cadinene $\quad(0.6 \%) \quad$ and alloaromadendréne $(0.5 \%)$ were present at $6.9 \%$. However, there was a low content of 1.8 cineole $(2.6 \%)$.

\section{Effect of the Eucalyptus camaldulensis essential oil on the larvae of Dermestes maculatus}

Figure 1 shows the efficacy of Eucalyptus camaldulensis essential oil against Dermestes maculatus larvae. No mortality was observed in the untreated control, in contrast to the control treated with actellic where no insect survived. With exposure duration of 24 hours, the Eucalyptus camaldulensis essential oil caused low mortalities which slightly exceeded $10 \%$ at all applied doses. However, with increasing duration of exposure, the highest 
mortality (33.3\%) was recorded after 72 hours of treatment at a dose of $40 \mu \mathrm{l}$ and at 120 hours at a dose of $60 \mu 1$.

\section{Effect of crushed fresh leaves of Eucalyptus camaldulensis on larvae of Dermestes maculatus}

Figure 2 shows the efficiency of fresh crushed leaves of Eucalyptus camaldulensis on the mortality of Dermestes maculatus larvae.
There is no mortality with the untreated control and full mortality with the actellic-treated control. Both the 24 hours and 72 hours exposures showed very low mortality rates, less than $15 \%$ at all dose. However, with the 120 hours duration, the $40 \mu \mathrm{l}$ dose is more effective than the $20 \mu \mathrm{l}$ dose on $D$. maculatus mortality with maxima of $40 \%$ for T6 and $26 \%$ for T5.

Table 2: Chemical constituents of essential oil from Eucalyptus camadulensis leaves collected from Dakar.

\begin{tabular}{|c|c|c|c|}
\hline Compounds & RIa & RI b & Area (\%) \\
\hline$\alpha$-thujene & 924 & 928 & $0.2 \pm \mathbf{0 . 1}$ \\
\hline$\alpha$-pinene & 932 & 936 & $4.5 \pm \mathbf{1 . 0}$ \\
\hline camphene & 936 & 953 & $0.1 \pm \mathbf{0 . 0}$ \\
\hline$\beta$-pinene & 974 & 982 & $26.8 \pm 0.6$ \\
\hline myrcene & 988 & 988 & $0.5 \pm \mathbf{0 . 1}$ \\
\hline$\alpha$-phellandrene & 1002 & 1008 & $0.1 \pm \mathbf{0 . 0}$ \\
\hline$\alpha$-terpinene & 1014 & 1019 & $\operatorname{tr}$ \\
\hline p-cymene & 1022 & 1027 & $2.2 \pm 0.2$ \\
\hline Limonene & 1024 & 1032 & $4.4 \pm \mathbf{0 . 4}$ \\
\hline$\beta$-phellandrene & 1026 & 1033 & $2.0 \pm 0.4$ \\
\hline 1.8-cineole & 1026 & 1036 & $2.6 \pm 0.2$ \\
\hline$\gamma$-terpinene & 1054 & 1060 & $0.1 \pm \mathbf{0 . 0}$ \\
\hline$\alpha$-terpinolene & 1086 & 1088 & $0.1 \pm \mathbf{0 . 1}$ \\
\hline Linalool & 1097 & 1103 & $0.1 \pm \mathbf{0 . 0}$ \\
\hline fenchol «exo » & 1122 & 1125 & $0.2 \pm \mathbf{0 . 0}$ \\
\hline$\alpha$-campholenal & 1126 & 1128 & $0.1 \pm \mathbf{0 . 0}$ \\
\hline trans-pinocarveol & 1139 & 1145 & $0.6 \mathbf{\pm 0 . 1}$ \\
\hline pinocarvone & 1165 & 1169 & $0.3 \pm \mathbf{0 . 1}$ \\
\hline borneol & 1169 & 1183 & $0.1 \pm \mathbf{0 . 0}$ \\
\hline terpinene-4ol & 1177 & 1186 & $0.8 \pm \mathbf{0 . 1}$ \\
\hline P-cymen-8ol & 1183 & 1189 & $0.1 \pm \mathbf{0 . 0}$ \\
\hline$\alpha$-terpineol & 1189 & 1193 & $0.4 \pm \mathbf{0 . 1}$ \\
\hline trans-p-mentha-1-(7)-8-dien-2ol & - & 1199 & $1.0 \pm \mathbf{0 . 1}$ \\
\hline myrtenol & 1196 & 1202 & $1.0 \pm 0.1$ \\
\hline trans-carveol & 1217 & 1222 & $0.1 \pm \mathbf{0 . 0}$ \\
\hline phellandral & 1273 & 1285 & $0.2 \pm \mathbf{0 . 0}$ \\
\hline
\end{tabular}


O. GUEYE et al. / Int. J. Biol. Chem. Sci. 15(4): 1435-1444, 2021

\begin{tabular}{|c|c|c|c|}
\hline thymol & 1290 & 1292 & $0.1 \pm \mathbf{0 . 0}$ \\
\hline carvacrol & 1299 & 1297 & $0.1 \pm \mathbf{0 . 0}$ \\
\hline bicycloelemene & 1333 & 1339 & $0.6 \pm \mathbf{0 . 4}$ \\
\hline$\alpha$-copaene & 1377 & 1380 & $0.1 \pm \mathbf{0 . 0}$ \\
\hline$\alpha$-elemene & 1381 & 1385 & $0.3 \pm \mathbf{0 . 0}$ \\
\hline$\beta$-elemène & 1391 & 1396 & $0.3 \pm \mathbf{0 . 0}$ \\
\hline$\alpha$-gurgunene & 1410 & 1419 & $0.1 \pm \mathbf{0 . 0}$ \\
\hline$\beta$-caryophyllene & 1421 & 1433 & $0.7 \pm \mathbf{0 . 1}$ \\
\hline$\beta$-gurjunene & 1434 & 1440 & $0.1 \pm \mathbf{0 . 0}$ \\
\hline calarene & 1437 & 1448 & $0.1 \pm \mathbf{0 . 0}$ \\
\hline Aromadendrene & 1441 & 1452 & $0.8 \pm \mathbf{0 . 1}$ \\
\hline$\alpha$-humulene & 1454 & 1458 & $0.1 \pm \mathbf{0 . 0}$ \\
\hline alloaromadendrène & 1460 & 1469 & $0.5 \pm \mathbf{0 . 0}$ \\
\hline$\gamma$-gurjunene & 1477 & 1474 & $1.1 \pm \mathbf{0 . 0}$ \\
\hline germacrène $\mathrm{D}$ & 1485 & 1487 & $0.1 \pm \mathbf{0 . 0}$ \\
\hline ledene & 1491 & 1496 & $0.1 \pm \mathbf{0 . 0}$ \\
\hline bicyclogermacrene & 1500 & 1503 & $1.1 \pm \mathbf{0 . 0}$ \\
\hline$\gamma$-cadinene & 1514 & 1508 & $0.6 \pm \mathbf{0 . 2}$ \\
\hline$\delta$-cadinene & 1523 & 1523 & $0.1 \pm \mathbf{0 . 0}$ \\
\hline cis-calamenene & - & 1526 & $0.1 \pm \mathbf{0 . 0}$ \\
\hline elemol & 1550 & 1556 & $1.4 \pm \mathbf{0 . 1}$ \\
\hline spathunelol & 1578 & 1576 & $0.1 \pm \mathbf{0 . 0}$ \\
\hline globulol & 1585 & 1585 & $0.4 \pm \mathbf{0 . 1}$ \\
\hline epiglobulol & - & 1591 & $7.9 \pm \mathbf{0 . 1}$ \\
\hline viridiflorol & 1593 & 1598 & $2.0 \pm 0.2$ \\
\hline 10-epir-eudesmol & 1619 & 1621 & $1.0 \pm \mathbf{0 . 1}$ \\
\hline$\gamma$-eudesmol & 1632 & 1645 & $6.1 \pm \mathbf{0 . 7}$ \\
\hline isospathulenol & 1637 & 1649 & $0.2 \pm \mathbf{0 . 0}$ \\
\hline hinesol & 1642 & 1653 & $0.4 \pm \mathbf{0 . 0}$ \\
\hline$\beta$-eudesmol & 1651 & 1660 & $0.1 \pm \mathbf{0 . 0}$ \\
\hline$\alpha$-eudesmol & 1654 & 1668 & $19.2 \pm \mathbf{0 . 7}$ \\
\hline
\end{tabular}

\begin{tabular}{cc}
\hline hydrocarbon monoterpenes & \\
\cline { 1 - 1 } Oxygenated Monoterpenes & 41.0 \\
\hline Hydrocarbon sesquiterpenes & 7.8 \\
\hline Oxygenated sesquiterpenes & 6.9 \\
\hline Total identified $(\%)$ & 38.8 \\
\hline
\end{tabular}

RIa = Retention index (Adams 2001 or Joulain and könig 1998) RIb = Retention index to C7-C30 


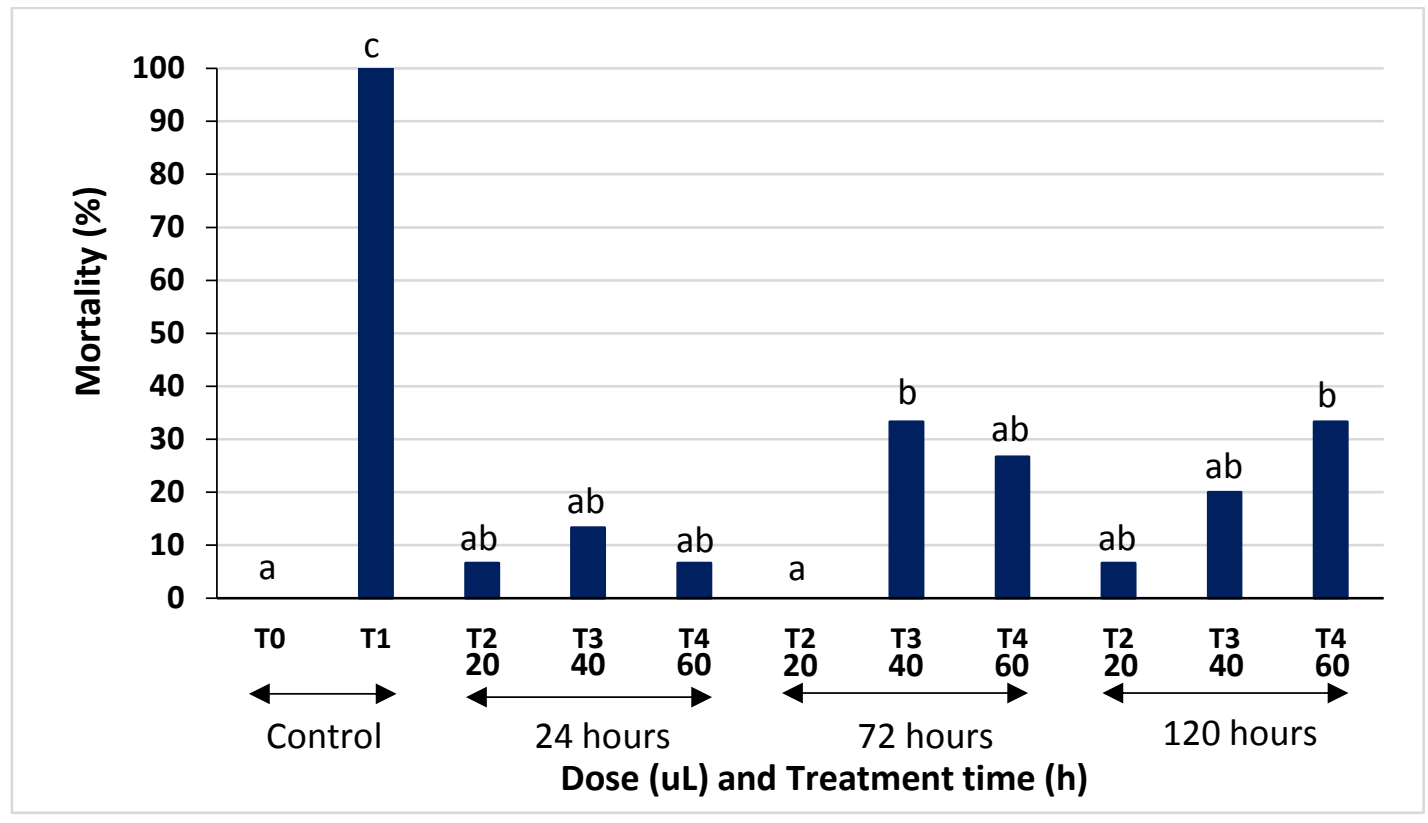

Figure 1: Effect of Eucalyptus camaldulensis essential oil on the mortality of Dermestes maculatus larvae as a function of dose and treatment time. Histograms followed by the same letter(s) are not statistically different $(\alpha \leq 0.05)$.

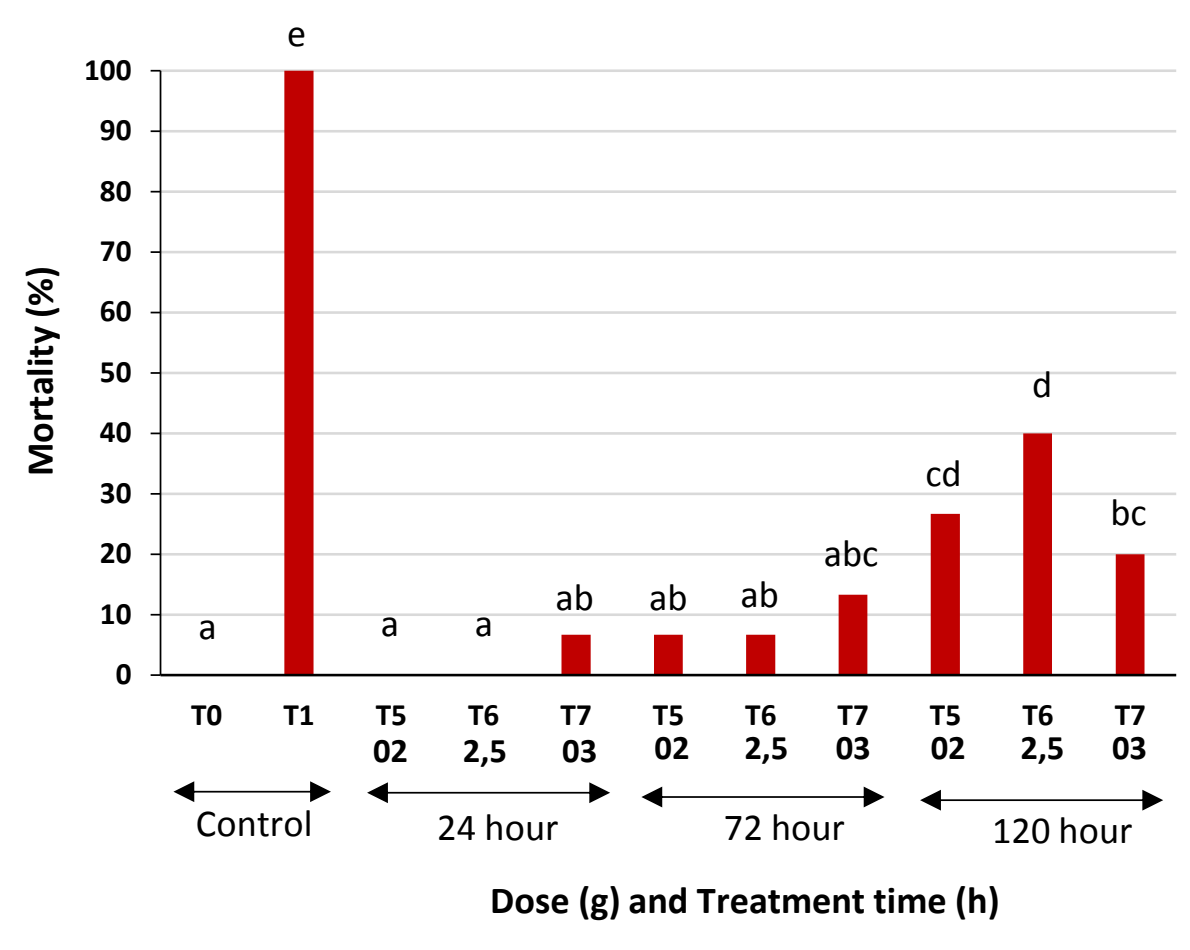

Figure 2: Effect of crushed fresh leaves of Eucalyptus camaldulensis on mortality of Dermestes maculatus larvae as a function of mass and treatment time. The histograms followed by the same letter are not statistically different $(\alpha \leq 0.05)$. 


\section{DISCUSSION}

The chemical composition of essential oils revealed high percentage of hydrocarbon monoterpenes ( $\beta$-pinène, $\alpha$-pinene and limonene). The major compounds were $\alpha$ pinene $(22.5 \%)$ and $\alpha$-phellandrene $(20.1 \%)$ as majority compounds and hydrocarbon monoterpenes as majority group (Cheng et al., 2009). These chemical features are close to those reported from the same species in Taiwan.

Oils from both of our samples contain low percentage of 1.8 -cineole $(2.55 \%)$. This compound has often been reported as a major component in essential oil from Eucalyptus. Francisco et al. (2001) found on $E$. camaldulensis collected from Maputo 43.4\% of 1.8-cineole, E. camaldulensis of Morocco revelead $50.69 \%$ and those of Iran $54.37 \%$ (Farah et al., 2002; Panahi et al., 2011). Though low in 1.8-cineole, percentages of our oils exceed those of an E. camaldulensis's oil of Algeria (Elaissi et al., 2012). The difference in composition of our oil and that of the other studies can be due to several factors. Thus, Figueiredo et al. (2010) reported abiotic (geographic variation, climat pollution...) and biotic (genetic factors and evolution, diseases and pests...) factors can impact the essential oils compositions.

The results of biological tests show that essential oil and the fresh crushed leaves of Eucalyptus camaldulensis can have a larvicidal effect. Indeed, the treatments act on the mortality of $D$. maculatus larvae, however these effects are strongly related to the dose used and the time of treatment.

The results of treatments with Eucalyptus camaldulensis essential oil reveal overall that $D$. maculatus is sensitive to tests especially with the $60 \mu \mathrm{L}$ dose for duration of exposure of 120 hours where mortality is $33.3 \%$. The mortality of D. maculatus larvae observed on dried and smoked Sardinella aurita treated with the essential oil could be due to a toxic effect of these compounds like $\beta$ pinene and $\alpha$-pinene. Indeed, Kounnki et al. (2007) reported that hydrocarbon monoterpenes like $\alpha$-pinene, $\beta$-pinene and $\Delta-3$ careen are toxic against insects and act as synergy. Lee et al. (2004) show the efficacy of eucalyptus essential oil against three types of insect pests like Sitophilus oryzae, Tribolium castaneum and Rhyzopertha dominica.

Tests with fresh crushed leaves of Eucalyptus camaldulensis gave more satisfactory results compared to treatments with the essential oil. Indeed, the mortality rate obtained is very low after 72 hours of exposure but reached $40 \%$ (p-value < 0.0001 ) after 120 hours with the $2.5 \mathrm{~g}$ dose. This larval mortality can also be due to the main active compounds present in the leaves of Eucalyptus camaldulensis. The insecticidal property of any plant material would depend on these active constituents. Indeed, the use of plant extracts (essential oils, plant powder, aqueous extracts...) for the control of insect pests of stored products has been widely reported (Fasakin, 2003; Mbaye et al., 2012; Jose et al., 2014). Mbaye et al. (2012) were obtained a repellent and biocidal activity of Crataeva Religiosa leaf powder against various stages of Dermestes spp. Similarly, Fasakin (2003) have demonstrated a potent effect of oil extracts from Piper guineense, Monodora myristica, Aframomum melegueta, Tithonia diversifolia and Nicotiana tabacum for killing all adults, pupae and eggs of D. maculatus, insect pest of smoked fish. According to Jose et al. (2014), Secamone afzelii powder at a dose of $3 \mathrm{~g}$ caused $48.8 \%$ mortality of Dermestes maculatus larvae in 72 hours and 56.8\% mortality in 120 hours of exposure to the powder. These results are in accordance with ours.

The results are significant but the mortality rates obtained are low. This could be due probably to the volatility, low doses used and also to the duration of exposure of the essential oil from E. camaldulensis fresh leaves.

\section{Conclusion}

The present study showed that fresh crushed leaves and the essential oil of Eucalyptus camaldulensis have interesting insecticidal properties against Dermestes maculatus larvaes. The experiments conducted in this study suggest the possibility of their use in protecting dried and smoked Sardinella aurita stocks; indeed low doses cause 
significant mortality rates. Crushed fresh leaves and the essential oil of Eucalyptus camaldulensis are a promising alternative to synthetic pesticides widely used and which are the cause of many public health problems. The larvicidal properties of the essential oil and fresh leaves of Eucalyptus camaldulensis are therefore useful in improving the sanitary quality and extending the shelf life of dried braised fish. A broader study on the others pests of stored dried and smoked Sardinella aurita would circumscribe its spectrum of effectiveness.

\section{COMPETING INTERESTS}

The authors declare that they have no competing interests.

\section{AUTHORS' CONTRIBUTIONS}

OG contributed to writing this manuscript and performed all the data analyses. NGF and MTG contributed to revising the manuscript. KS and LK contributed to the study design. EBN performed all the analyses of the essential oil.

\section{ACKNOWLEDGMENTS}

Many thanks to WBI for their support.

\section{REFERENCES}

Abbott WS. 1925. A method of computing the effectiveness of an insecticide. Journal of Economic Entomology, 18: 265-267. DOI:

https://doi.org/10.1093/jee/18.2.265a

Adams RP. 2001. Identification of Essential Oil Components by Gas Chromatography/Quadrupole Mass Spectroscopy. Allured Publishing, Carol Stream, IL, USA, 456p. DOI: https://lib.ugent.be/catalog/rug01:000800 424

Cheng SS, Huang CG, Chen YJ, Yu JJ, Chene WJ, Chang ST. 2009. Chemical compositions and larvicidal activities of leaf essential oils from two eucalyptus species. Bioresource Technology, 100: 452-456.

Don-Pedre KN. 1985. Tocicity of some cutris peels to Dermestes maculatus and Callosobruchus maculatus. Journal of
Stored of Products Research, 21: 31-34. DOI: http://dx.doi.org/10.1016/0022474x (85)90057-8

Elaissi A, Rouis Z, Mabrouk S, Salah KBH, Aouni M, Khouja ML, Farhat F, Chemli R, Harzallah-Skhiri F. 2012. Correlation Between Chemical Composition and Antibacterial Activity of Essential Oils from Fifteen Eucalyptus Species Growing in the Korbous and Jbel Abderrahman Arboreta (North East Tunisia). Molecules, 17: 3044-3057. DOI: https://doi.org/10.3390/molecules 170330 44

Fall NG, Tounkara LT, Diop MB, Thiaw OT, Thonart P. 2014. Etude socioéconomique et technologique de la production du poisson fermenté et séché (Guedj) au Sénégal. Int. J. Biol. Chem. Sci., 8(6): 2523-2538. DOI: http://dx.doi.org/10.4314/ijbcs.v8i6.15

Fasakin EA. 2003. Use of some plant oil extracts as surface protectant against storage insect Pest Dermestes maculatus de geer on smoked fish. Department of fisheries and wildlife. Federal University of Technology, Akure, Nigeria. 3(4):1-6.

Farah A, Fechtal M, Chaouch A. 2002. Effet de l'hybridation interspécifique sur la teneur et la composition chimique des huiles essentielles d'eucalyptus cultivés au Maroc. Biotechnol. Agron. Soc. Environ, 6(3) : $\quad 163-169 . \quad$ DOI: https://popups.uliege.be/17804507/index.php?id=14637

Figueiredo AC, Barroso JG, Pedro LG, Scheffer JJ. 2008. Factors affecting secondary metabolite production in plants: volatile components and essential oils. Flavour and Fragrance Journal, 23(4): 213-226. DOI: https://doi.org/10.1002/ffj.1875

Francisco JC, Järvenpää EP, Huopalahti R, Sivik B. 2001. Comparison of Eucalyptus camaldulensis Dehn. Oils from Mozambique As Obtained by Hydrodistillation and Supercritical Carbon Dioxide Extraction. Journal of Agricultural and Food Chemistry, 49: 2339-2342.

DOI: 
Guèye MT, Seck D, Wathelet JP, Lognay G. 2011. Lutte contre les ravageurs des stocks de céréales et de légumineuses au Sénégal et en Afrique Occidentale : synthèse bibliographique. Biotechnology Agronomy Society Environment, 15: 183194. DOI: https://popups.uliege.be/17804507/index.php?id=7108

Gueye MT. 2012. Gestion intégrée des ravageurs de céréales et de légumineuses stockées au Sénégal par l'utilisation de substances issues de plantes. Thèse de doctorat unique. Université Cheikh Anta Diop de Dakar, Dakar, p. 216.

Gueye-NDiaye A. 1991. Dermestes maculatus (Degeer), principal déprédateur des produits halieutiques transformés au Sénégal. Proceedings of the 5th IWCSPP. Bordeaux, France, Septembre 9-14, 1990, $1: 71-78$.

Joulain D, Konig WA. 1998. The Atlas of Spectral Data of Sesquiterpene Hydrocarbons. EB-Verlag, Hamburg.

Jose AR, Adesina JM. 2014. Larval Susceptibility of Dermestes maculatus (Degeer, 1776) (Coleoptera: Dermestidae) to Secamone afzelii (Schult) K Schum Leaf Powder on Smoke-Dried Fish, International Journal of Aquaculture, 4(17): 102-107. DOI: https://doi.org/10.5376/ija2014.04.0017

Koch KG, Chapman K, Louis J, Heng-Moss T, Sarath G. 2016. Plant Tolerance: A Unique Approach to Control Hemipteran Pests. Frontiers in Plant Science, 7: 11363.

DOI: https://doi.org/10.3389/fpls.2016.01363

Kouninki H, Hance T, Noudjou FA, Lognay G, Malaisse F, Ngassoum MB, Mapongmetsem PM, Ngamo LST, Haubruge E. 2007. Toxicity of some terpenoids of essential oils of Xylopia aethiopica from Cameroon against Sitophilus zeamais Motschulsky. Journal of Applied Entomology, 131 (4): 1-8. DOI: https://doi.org/10.1111/j.14390418.2007.01154.x

Lee BH, Annis PC, Tumaalii F, Choi WS. 2004. Fumigant toxicity of essential oils. Journal of Stored Products Research,
Oxford, 40: 553-564. DOI: https://doi.org/10.1016/j.jspr.2003.09.00 1

Locatelli DP, Stampini M, 2005. Proceedings of the Fifth International Conference on Urban Pests. Chow-Yang L, Robinson WH (eds), P\&Y Design Network: Malaysia; p. 527.

Mbaye L. 2005. Etat des lieux de la transformation artisanale des produits halieutiques au Sénégal, p. 40.

Mbaye NN, Sarr M, Gueye-Ndiaye A, Samb A, Sembene M. 2012. Identification and Quantification of Synthetic Insecticides Used Against Pests Smoked-Dried Fish in Senegal: Risk Assessment. International Journal of Science and Advanced Technology, 13(2): 73-80.

Medhi SM, Reza SA, Mahnaz K, Reza AM, Abbas H, Fatemeh M, Hassan V. 2010. Phytochemistry and larvicidal activity of Eucalyptus camaldulensis against malaria vector, Anopheles stephensi. Asian Pacific Journal of Tropical Medicine, 6(3): $\quad$ 841-845. https://doi.org/10.1016/s1995-7645 (10)60203-9

Ndiaye EB, Diop MB, Gueye MT, Ndiaye I, Diop SM., Fauconnier ML, Lognay G. 2018. Characterization of essential oils and hydrosols from senegalese Eucalyptus camaldulensis Dehnh, Journal of Essential Oil Research, 30(2): 131-141.

DOI: https://doi.org/10.1080/10412905.2017.1 420554

Panahi Y, Sattari M, Babaie AP, Beiraghdar F, Ranjbar R, Joo AH, Bigdeli M. 2011. The Essential Oils Activity of Eucalyptus polycarpa, E. largiflorence, $E$. malliodora and E. camaldulensis on Staphylococcus aureus. Iranian Journal of Pharmaceutical Research, 10 (1): 4348.

Siddiqui BS, Sultana I, Begum S. 2000. Triterpénoidal constituents from Eucalyptus camaldulensis var. obtusa leaves. Phytochemistry, 54: 861-865. DOI: https://doi.org/10.1016/s00319422(00)00058-3 